\title{
GC-MS Analysis of Commercially Available Allium sativum and Trigonella foenum-graecum Essential Oils and their Antimicrobial Activities
}

\author{
Syed Amir Ashraf ${ }^{1}$ D , Mushtaq Ahmad Khan ${ }^{2}$ (D) , Amir Mahgoub Awadelkareem ${ }^{1}$ (D), \\ Shaikh Tajuddin ${ }^{3}$, Md Faruque Ahmad ${ }^{4}$ (D) and Talib Hussain ${ }^{5 *}$ (D)
}

${ }^{1}$ Department of Clinical Nutrition, College of Applied Medical Sciences, University of Hail, Hail 2440, Saudi Arabia. ${ }^{2}$ MDPTU, College of Applied Medical Sciences, University of Hail, Hail 2440, Saudi Arabia. ${ }^{3}$ Department of Food Technology, FEIS, Hamdard University, Delhi - 110 062, India. ${ }^{4}$ Department of Clinical Nutrition, College of Applied Medical Sciences, Jazan University, Jazan, Saudi Arabia. ${ }^{5}$ Department of Pharmacology \& Toxicology, College of Pharmacy, University of Hail, Hail 2440, Saudi Arabia.

\begin{abstract}
Food preservation and safety is drawing more attention globally due to the increasing prevalence of food-borne diseases. The natural methods of food preservation are considered safer compared to methods using synthetic preservatives. The essential oils with natural preservative properties could be useful for food safety and preservation. The objective of this study was to analyze the chemical composition of commercially available Allium sativum and Trigonella foenum-graecum essential oils by gas chromatography-mass spectroscopy (GC-MS). The antimicrobial activities of Allium sativum and Trigonella foenum-graecum essential oils were determined by agar well diffusion technique. The GC-MS analysis of Garlic essential oil (GEO) revealed that, Allyl methyl trisulfide (13.10\%), Di-allyl sulfide (9.47\%) and Di-allyl tetrasulfide (4.38\%) were the major components, while methanolic extract of Fenugreek essential oil (FEO) showed limonene (12.92\%), Silane trimethylphenyl (10.71\%), carvone (4.57\%) and Trigolline $(0.38 \%)$ as major components. The results of our study showed a significant antimicrobial activity of GEO and FEO against the tested microbial strains, which indicates the presence of broadspectrum antimicrobial constituents in GEO and FEO. However, further studies are needed for individual bioactive components and safety aspects for their application in food preservation.
\end{abstract}

Keywords: Bio-active components, Essential oils, GC-MS; Agar well assay; Antimicrobial activity.

*Correspondence: talib2410@gmail.com; +966-591491521

(Received: 19 September 2019; accepted: 19 December 2019)

Citation: Syed Amir Ashraf, Mushtaq Ahmad Khan, Amir Mahgoub Awadelkareem, Shaikh Tajuddin, Md Faruque Ahmad and Talib Hussain, GC-MS Analysis of Commercially Available Allium sativum and Trigonella foenum-graecum Essential Oils and their Antimicrobial Activities, J Pure App/ Microbiol., 2019; 13(4):2545-2552. https://doi.org/10.22207/JPAM.13.4.69

(C) The Author(s) 2019. Open Access. This article is distributed under the terms of the Creative Commons Attribution 4.0 International License which permits unrestricted use, sharing, distribution, and reproduction in any medium, provided you give appropriate credit to the original author(s) and the source, provide a link to the Creative Commons license, and indicate if changes were made. 


\section{INTRODUCTION}

The role of essential oils (EOs) in food preservation has been extensively studied due to the undesirable effects of synthetic preservatives used in food industries ${ }^{1}$. Furthermore, rise in foodborne diseases worldwide put people at the risk of health hazards, calling for more effective, safe and natural source of food preservation. To improve the food safety, one of the options in modern time is to study and investigate the antimicrobial activities of the bioactive compounds and use them in food industry. Antimicrobial properties of naturally occurring bioactive components restrict the use of chemical antimicrobial agents, which may possess a potential human health hazard ${ }^{2}$. The main bioactive components of EOs are mono and sesquiterpene, which are believed to be responsible for their biological activity; therefore, the identification of these bioactive components from various plant sources has become meaningful task. Gas chromatography (GC) or gas chromatography-mass spectrometry (GC-MS) is used exclusively for the qualitative analysis of the volatiles compounds ${ }^{3}$. Additionally, the antimicrobial properties of volatile components are known for decades and because of their potential microbial growth inhibition activity, these volatile components are being investigated as a substitute to synthetic chemical preservatives in food industries ${ }^{4}$. Since ancient times, herbs and spices are added in food and food products, not only as seasoning agent but also as a method of preservation ${ }^{5}$. Plant materials such as Garlic essential oil (GEO) and Fenugreek essential oil (FEO) with antibacterial properties could have a possible application in food preservation, for example, several studies have proved that garlic (Allium sativum) possesses a significant antimicrobial activity. Antimicrobial activity of garlic extracts has been reported against bacteria and fungi ${ }^{6}$. GEO have been reported to contain antibiotic, immunomodulatory, antioxidant, anti-inflammatory, cardiovascular-protecting and hypoglycemic effects ${ }^{7,8}$. Garlic can be used as an effective source for food preservation and also as a natural herbal antibiotic ${ }^{9}$. Moreover, fenugreek seed (Trigonella foenum) oil has been known for their antimicrobial properties against food borne pathogens, thus it could be potentially useful in increasing shelf life of food products. FEO has been reported to have antimicrobial, anti-diabetic, anticancer, anti-fertility, and anti-parasitic activity ${ }^{10}$.

Thus the growing demand of natural ingredients like essential oils in food preservation appears as a viable and healthy alternative to synthetic preservatives. Based upon our literature survey, we did not find any reports on GC-MS analysis as well as antimicrobial activity of commercially available essential oils. Therefore, this work was designed to evaluate the chemical composition and antimicrobial activity of commercial sample (GEO and FEO) against various microbial pathogens.

\section{MATERIALS AND METHODS Sample Collection}

Garlic essential oil (GEO) and fenugreek essential oil (FEO) were procured from the local market of $\mathrm{Ha}^{\prime} \mathrm{il}$, Kingdom of Saudi Arabia in December 2018. Selected samples were chosen based upon literature survey and their possible application in food industry. Quality of the oils was ascertained to be more than $98 \%$ pure.

Gas chromatography mass spectrometry (GC-MS) GC-MS (Thermo Scientific, Triple quadropole MS, TSQ 8000) analysis were performed for the GEO and FEO using two fused silica capillary column TG-5MS, ( $30 \mathrm{~m} \times 0.25 \mathrm{~mm} \times$ $0.25 \mu \mathrm{m})$. Moreover, temperature for detector and injector were fixed at $250^{\circ} \mathrm{C}$ as well as $220^{\circ} \mathrm{C}$ and helium ( $1 \mathrm{~mL} / \mathrm{min})$ as a carrier gas was employed for this study. Samples $(1 \mu \mathrm{L})$ dissolved in methanol were introduced into column which was initially fixed at $50^{\circ} \mathrm{C}$ for $1 \mathrm{~min}$ and concurrently raised to $280^{\circ} \mathrm{C}$ by slowly raising temperature of $5^{\circ} \mathrm{C} /$ min. Both the samples were run for 30 minutes and analysis of obtained chromatograms was performed. Identification and characterization of various compounds were made by comparing relative retention time (RT) and mass spectra of samples with reference standards by using National Institute of Standards and Technology (NIST) library database ${ }^{5}$.

\section{Test Organisms}

Micro-organism used in this study was procured from ATCC (American Type Culture Collection from LGC Promochem, Banglore INDIA as well as MTCC strains were procured from Institute of Microbial Technology (IMTECH), Chandigarh, INDIA. Fungal strains used in this study 
was Aspergillus niger (MTCC 2196), Penicillium pinophilium (MTCC 2192), Candida albicans (ATCC 10231), Aspergillus flavus (MTCC 2798), and Saccharomyces cerevisiae (MTCC 786). However, bacterial strains selected for this study was Rhodococus equi (ATCC 6939), Listeria innocua (ATCC 33090), Listeria monocytogenes (ATCC 19111), Vibrio parahaemolyticus (ATCC 17802), Enteococcus hirae (ATCC10541), Escherichia coli (ATCC 15597), Cronobacter sakazakii (ATCC 29544), Listeria ivanovii (ATCC 19119), Bacillus cereus (MTCC 430), Shigella (MTCC 1457), Enteococcus faecalis (MTCC 439), Salmonella enterica (MTCC 733), Staphylococcus aureus (MTCC 96), Clostridium perfringens (MTCC 450), Vibrio cholera MTCC (3906), Enterobacter aerogenes (MTCC 111), Salmonella typhi (MTCC 733), Klebsiella pneumonia (MTCC 109), Micrococcus luteus (MTCC 2470), Pseudomonas aeruginosa (MTCC 741) and Citrobacter freundii (MTCC 1658).

\section{Culture medium and inoculum preparation}

Pure test organisms of all the selected micro-organism (Bacteria and fungus) were subcultured onto fresh plates of Mueller-Hinton agar (Hi Media laboratories) for $24 \mathrm{~h}$ and Saboraud dextrose agar (Hi Media laboratories) for 5-7 days at $37^{\circ} \mathrm{C}$ for bacteria and fungi, respectively. All the test organisms were incubated as specified for each organism for a period of 18- $24 \mathrm{~h}^{11}$.

\section{Agar well diffusion assay}

Antimicrobial activity of GEO and FEO were analyzed by using agar well diffusion assay techniques ${ }^{5}$. Muller-Hinton Agar and Sabouraud Dextrose Agar plates were used for antibacterial and antifungal activity, respectively. $100 \mu \mathrm{L}$ standard bacterial and fungal inoculums were spread over the sterile plates and subsequently $8 \mathrm{~mm}$ diameter wells were borer over the respective agar plates. Afterwards, $100 \mu \mathrm{L}$ GEO and FEO were filled into the Muller-Hinton agar and Sabouraud Dextrose agar plate wells and kept at room temperature for 1 hour for proper diffusion and incubated for $37 \mathrm{C}$ for 24 hours and $30 \mathrm{C}$ for $3-5$ days respectively ${ }^{12}$. All the samples were prepared in triplicates, essential oils having antimicrobial activity inhibited the microbial growth and the clear zones were formed. The zones of inhibition were measured in millimeters ${ }^{13}$.

Statistical analysis

All the experimental results were carried out in triplicates and expressed as mean \pm SEM (Standard Error of Means) of three independent experiments $(n=3)$.

\section{RESULTS AND DISCUSSION}

Characterization of chemical constituents using Gas Chromatography-Mass Spectrometry

Identification of various chemical components present in GEO and FEO were determined by GC-MS. The full scan GC-MS chromatograms are presented in Fig. $1 \mathrm{~A}$ and $1 \mathrm{~B}$. Based upon the GC-MS chromatogram analysis, major components identified are presented in table 1 . The identification of bioactive components are determined by comparing the chromatogram peak obtained in our samples with reference peaks as mentioned in National Institute of Standards and Technology (NIST) Library 5 . Furthermore, reference peaks were directly compared with the retention time and mass spectral data obtained in GEO and FEO sample chromatogram. According to GEO chromatogram (figure $1 \mathrm{~A}$ ), nineteen distinctive peaks were analyzed by GC-MS. Moreover, the major bioactive components analyzed by GC-MS were found to be Allyl methyl trisulfide (13.10\%), Diallyl sulfide (9.47\%), c-Sitosterol (6.15\%), Diallyl tetrasulfide (4.38\%) and Allyl methyl disulfide (3.40).. The results of the current study were comparable to previous studies ${ }^{14-16}$. Previously, allicin degradation has been proved responsible for the presence of sulphide compounds in oils. Moreover, formation of allicin in garlic occurs due to release of allinase enzyme after crushing garlic bulb. Subsequently, allicin is converted into alliin and because allicin is very unstable compound, it suddenly undergo reactions to form sulphur derivative components ${ }^{17}$. The GC-MS analysis of Chinese commercial GEO sample, which reports diallyl disulphide (45.1-63.2\%) as highest components compared to other diallyl sulfide (4.5-11.4\%), and diallyl tetrasulfide (6.3-10.5\%) ${ }^{18}$. However, our results showed that GEO sample had highest amount of Allyl methyl trisulphide followed by diallyl sulphide and diallyl tetra sulphide. The differences obtained in sulphide content could be due the geographical as well as the process of distillation to obtain the essential oils.

On the other hand, FEO chromatogram showed seventeen distinctive peaks analyzed by 

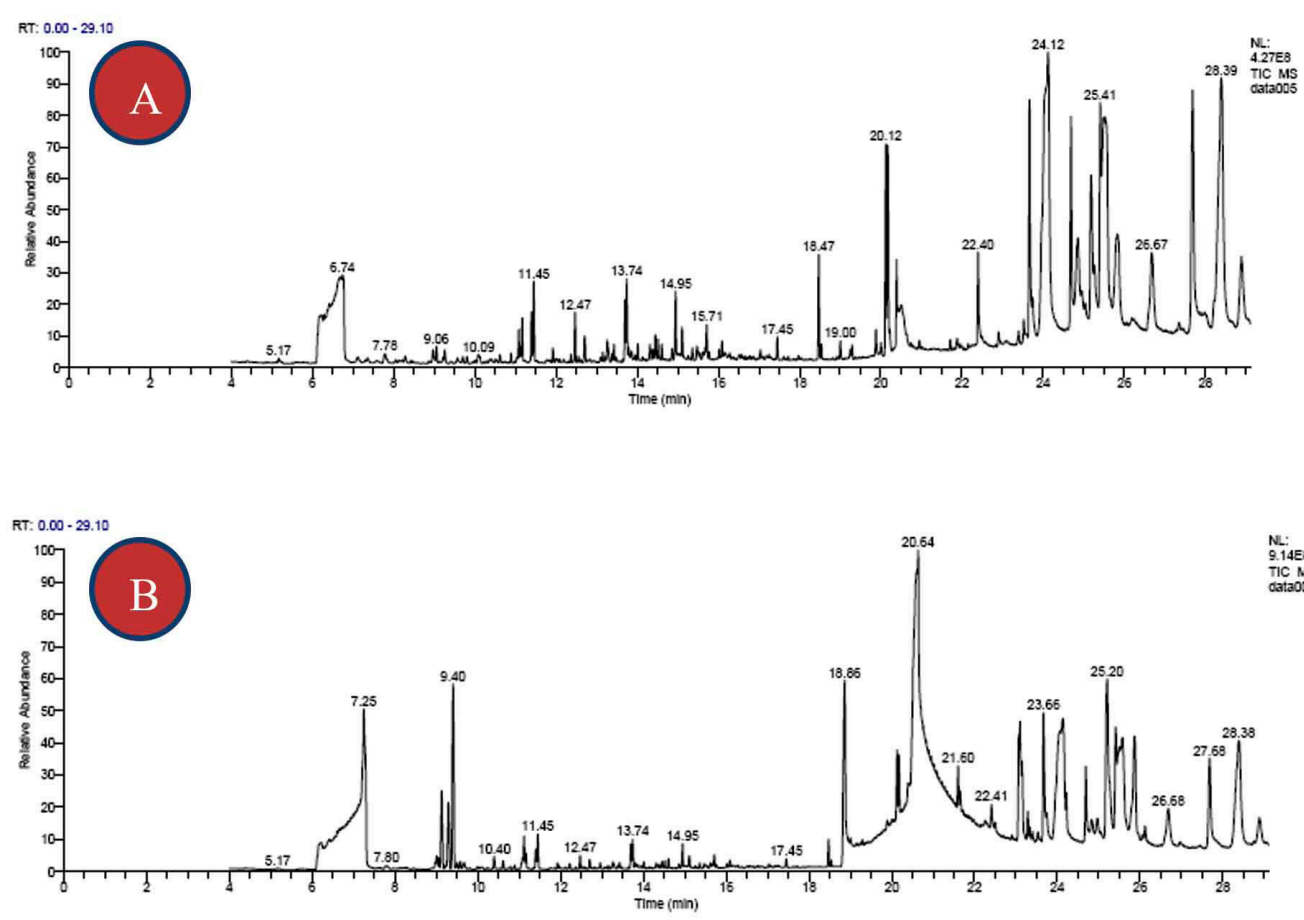

Fig. 1. GC-MS chromatogram of the bioactive compounds present in (A) Garlic essential oil and (B) Fenugreek essential oil

GC-MS and all the major components identified are presented in table 1 . The major components present in the fenugreek EO were identified as limonene (12.92\%), c-Sitosterol (9.58\%), Carvone (4.57\%), Campesterol (3.60\%), Stigmasterol (2.83\%), Cedrane-8-propoxy (1.50\%) and Trigolline $(0.38 \%)$. The previous scientific reports revealed that, stolones-furanones are the principle volatile compounds present in fenugreek oils ${ }^{19}$. The bioactive component sigmasterol present in FO have been reported to decrease blood cholesterol level $^{20}$.

\section{Antimicrobial activity of essential oils}

Both Garlic and Fenugreek essentials oils were investigated for in-vitro antimicrobial activity and both GEO and FEO showed positive antibacterial activity against Gram-negative, Gram-positive bacteria and few fungal strains tested in this study ${ }^{21}$. Antimicrobial activities of tested microorganisms are presented in Table 2 \& Table 3. GEO showed antimicrobial activity against all the tested strains. Among the fungal strains, Aspergillus flavus showed the maximum inhibition zone $(18.3 \pm 0.29)$ followed by Candida albicans (18.1 \pm 0.41). Saccharomyces cerevisiae showed least zone of inhibition ( $12.5 \pm 0.29)$. Clotrimazole $(50 \mu \mathrm{g} / \mathrm{ml})$ were tested against the stated fungal strains and their inhibition zone found to be in the range of $26.4 \pm 0.42-35.2 \pm 0.47$. Micrococcus luteus showed the highest sensitivity (20.8 \pm 0.28) followed by Escherichia coli, Bacillus cereus, Enteococcus hirae and Listeria monocytogenes were the least sensitive $(5.2 \pm 0.21)$ to GEO. Tetracycline $(50 \mu \mathrm{g} / \mathrm{ml})$ antibacterial activity varied from ( $9.6 \pm 0.48-31.1 \pm 0.38)$. Clotrimazole and tetracycline antimicrobial standards were compared with GEO, which showed t GEO had a broad antimicrobial potential. The antibacterial activity of GEO has been attributed to the presence of allicin ${ }^{21}$. Additionally, allicin contains thiosulfnate group (-S(O)-S- group) found in the GEO extract is proved to possess antimicrobial properties $^{22}$. One of the previous studies have revealed that, $\mathrm{SH}$ group of cellular proteins react with $-\mathrm{S}(\mathrm{O})-\mathrm{S}$ - group, for the production of mixed disulfides ${ }^{23}$. Furthermore, the antimicrobial activity of GEO has been reported mainly because of the presence of organosulfur compounds such as allicin, ajoene and diallyl sulfides ${ }^{24}$. In addition, Mousumi \& Prabir also reported that, garlic 
Table 1. Garlic and fenugreek essential oil composition obtained by gas chromatography mass spectrophotometry

\begin{tabular}{lccc}
\hline RT Compound Name & $\begin{array}{c}\text { Molecular } \\
\text { Formula }\end{array}$ & Area \% Identification \\
\hline
\end{tabular}

\begin{tabular}{|c|c|c|c|c|}
\hline \multicolumn{5}{|c|}{ Garlic Essential Oil (GEO) } \\
\hline 7.25 & Benzyl alcohol & $\mathrm{C}_{7} \mathrm{H}_{8} \mathrm{O}$ & 5.79 & MS, RI \\
\hline 9.13 & I-Menthone & $\mathrm{C}_{10} \mathrm{H}_{18} \mathrm{O}$ & 1.82 & MS, RI \\
\hline 9.29 & p-Menthan-3-one & $\mathrm{C}_{10} \mathrm{H}_{18} \mathrm{O}$ & 1.63 & MS, RI \\
\hline 9.67 & a-Terpineol & $\mathrm{C}_{10} \mathrm{H}_{18} \mathrm{O}$ & 0.19 & MS, RI \\
\hline 10.40 & Pulegone & $\mathrm{C}_{10} \mathrm{H}_{16} \mathrm{O}$ & 0.26 & MS, RI \\
\hline 28.38 & c-Sitosterol & $\mathrm{C}_{29} \mathrm{H}_{50}{ }^{16} \mathrm{O}$ & 6.15 & $\mathrm{MS}, \mathrm{RI}$ \\
\hline 9.40 & Diallyl tetrasulfide & $\mathrm{C}_{10} \mathrm{H}_{20} \mathrm{O}$ & 4.38 & MS, RI \\
\hline 11.12 & Menthyl acetate & $\mathrm{C}_{12} \mathrm{H}_{22} \mathrm{O}_{2}$ & 1.05 & MS, RI \\
\hline 11.45 & $\begin{array}{l}\text { 1-Triethylsilyloxy- } \\
\text { heptadecane }\end{array}$ & $\mathrm{C}_{23} \mathrm{H}_{50} \mathrm{OSi}$ & 0.99 & MS, RI \\
\hline 12.70 & $\begin{array}{l}\text { 2,4,7,9-Tetramethyl- } \\
\text { 5decyn4,7diol }\end{array}$ & $\mathrm{C}_{14} \mathrm{H}_{26} \mathrm{O}_{2}$ & 0.19 & MS, RI \\
\hline 15.71 & $\begin{array}{l}\text { 1-Monolinoleoylglycerol } \\
\text { Tri-methylsilyl ether }\end{array}$ & $\mathrm{C}_{27} \mathrm{H}_{54} \mathrm{O}_{4} \mathrm{Si}_{2}$ & 0.33 & MS, RI \\
\hline 18.47 & $\begin{array}{l}\text { Hexadecanoic acid, } \\
\text { methylester }\end{array}$ & $\mathrm{C}_{17} \mathrm{H}_{34} \mathrm{O}_{2}$ & 0.43 & MS, RI \\
\hline 18.86 & $\begin{array}{l}\text { 1-(+)-Ascorbic acid 2, } \\
\text { 6-dihexadecanoate }\end{array}$ & $\mathrm{C}_{38} \mathrm{H}_{68} \mathrm{O}_{8}$ & 5.66 & MS, RI \\
\hline 20.60 & Allyl methyl tri-sulfide & $\mathrm{C}_{18} \mathrm{H}_{32} \mathrm{O}_{2}$ & 13.10 & MS, RI \\
\hline 23.09 & Oleic acid, 3-hydroxypropylester & $\mathrm{C}_{21} \mathrm{H}_{40} \mathrm{O}_{3}$ & 5.61 & MS, RI \\
\hline 23.66 & Allyl methyl disulfide & ${ }_{38}^{4} \mathrm{O}_{4}^{3}$ & 3.40 & MS, RI \\
\hline 24.05 & $\begin{array}{l}\text { 2,6-Bis(3,4methylenedioxyphenyl)- } \\
\text { 3,7-dioxabicyclo (3.3.0)octane }\end{array}$ & $\mathrm{C}_{20} \mathrm{H}_{18} \mathrm{O}_{6}$ & 5.16 & MS, RI \\
\hline 24.13 & $\begin{array}{c}\text { 2,6-Bis(3,4-methylenedioxyphenyl)- } \\
\text { 3,7-dioxabicyclo(3.3.0)octane }\end{array}$ & $\mathrm{C}_{20} \mathrm{H}_{18} \mathrm{O}_{6}$ & 4.12 & MS, RI \\
\hline 25.20 & Diallyl sulfide & $\mathrm{C}_{21} \mathrm{H}_{40} \mathrm{O}_{4}$ & 9.47 & MS, RI \\
\hline \multicolumn{5}{|c|}{ Fenugreek Essential Oil (FEO) } \\
\hline 12.70 & $\begin{array}{l}\text { 2,4,7,9-Tetramethyl-5- } \mathrm{C}_{14} \mathrm{H}_{26} \mathrm{O}_{2} \\
\text { decyn-4,7-diol }\end{array}$ & 0.35 & MS, RI & \\
\hline 13.27 & Dimethyl phthalate & $\mathrm{C}_{10} \mathrm{H}_{10} \mathrm{O}_{4}$ & 0.44 & $\mathrm{MS}, \mathrm{RI}$ \\
\hline 13.43 & n-Cetyl alcohol & $\mathrm{C}_{16} \mathrm{H}_{34} \mathrm{O}$ & 0.33 & MS, RI \\
\hline 18.47 & Hexadecanoic acid, methyl ester & $\mathrm{C}_{17} \mathrm{H}_{34} \mathrm{O}_{2}$ & 1.19 & MS, RI \\
\hline 19.29 & $\begin{array}{c}\text { 5,8,11-Heptadecatriynoicacid, } \\
\text { methyl ester }\end{array}$ & $\mathrm{C}_{18} \mathrm{H}_{24} \mathrm{O}_{2}$ & 0.28 & MS, RI \\
\hline 19.88 & Trigolline & $\mathrm{C}_{28} \mathrm{H}_{58} \mathrm{O}_{9}$ & 0.38 & MS, RI \\
\hline 20.39 & Methyl stearate & $\mathrm{C}_{19} \mathrm{H}_{38} \mathrm{O}_{2}$ & 1.64 & MS, RI \\
\hline 20.49 & Cedryl propyl ether & $\mathrm{C}_{18} \mathrm{H}_{32} \mathrm{O}$ & 1.50 & MS, RI \\
\hline 22.90 & $\begin{array}{l}\text { 1-Monolinoleoylglycerol- } \\
\text { trimethylsilyl ether }\end{array}$ & $\mathrm{C}_{27} \mathrm{H}_{54} \mathrm{O}_{4} \mathrm{Si}_{2}$ & 0.29 & MS, RI \\
\hline 23.66 & $\begin{array}{l}\text { Hexadecanoic acid,2-hydroxy- } \\
\text { 1-(hydroxymethyl)ethyl ester }\end{array}$ & $\mathrm{C}_{19} \mathrm{H}_{38} \mathrm{O}_{4}$ & 4.04 & MS, RI \\
\hline 24.12 & Limonene & $\mathrm{C}_{20} \mathrm{H}_{18} \mathrm{O}_{6}$ & 12.92 & MS, RI \\
\hline 24.68 & Nonaethylene glycol & $\mathrm{C}_{18}^{20} \mathrm{H}_{38} \mathrm{O}_{10}$ & 3.57 & MS, RI \\
\hline 25.83 & Campesterol & $\mathrm{C}_{28} \mathrm{H}_{48} \mathrm{O}$ & 3.60 & MS, RI \\
\hline 26.67 & Stigmasterol & $\mathrm{C}_{29}^{20} \mathrm{H}_{48}^{40} \mathrm{O}$ & 2.83 & MS, RI \\
\hline 27.68 & Carvone & $\mathrm{C}_{18} \mathrm{H}_{38} \mathrm{O}_{10}$ & 4.57 & MS, RI \\
\hline 28.39 & c-Sitosterol & $\mathrm{C}_{29}^{18} \mathrm{H}_{50} \mathrm{O}$ & 9.58 & MS, RI \\
\hline
\end{tabular}


Table 2. Antifungal activity of essential oils using Agar diffusion method

\begin{tabular}{lccc}
\hline Microorganisms & \multicolumn{3}{c}{ Zone of Inhibition in diameter $(\mathrm{mm})$} \\
\cline { 2 - 4 } & GEO & FEO & $\begin{array}{c}\text { Clotrimazole } \\
(50 \mu \mathrm{g} / \mathrm{ml})\end{array}$ \\
\hline Aspergillus niger & $16.1 \pm 0.43$ & $4.9 \pm 0.26$ & $28.2 \pm 0.37$ \\
Aspergillus flavus & $18.3 \pm 0.29$ & $6.1 \pm 0.62$ & $26.4 \pm 0.42$ \\
Candida albicans & $18.1 \pm 0.41$ & $8.1 \pm 0.56$ & $27.1 \pm 0.33$ \\
Penicillium pinophilium & $14.6 \pm 0.13$ & $3.1 \pm 0.17$ & $37.5 \pm 0.19$ \\
Saccharomyces cerevisiae & $12.5 \pm 0.29$ & $5.2 \pm 0.08$ & $35.2 \pm 0.47$ \\
\hline
\end{tabular}

Values are expressed as Mean \pm SEM (Standard Error of Means)

extracts possesses a very strong antibacterial activity against Staphylococcus aureus, Escherichia coli ${ }^{25}$. In addition to that, garlic juice is also reported to shown antibacterial activity against, Escherichia coli and Staphylococcus aureus ${ }^{26,27}$. Yin et al., reported that, Salmonella typhimurium growth in ground beef were effectively inhibited by GEO derived organosulfur compounds ${ }^{28}$. Antimicrobial activity of FEO showed poor results against the tested microorganism, when compared with standard clotrimazole and tetracyclines $(50 \mu)$ $\mathrm{ml}$ ). Zone of inhibition for both the standards varied from $(26.4 \pm 0.42-35.2 \pm 0.47)$ and $(9.6 \pm$ $0.48-31.1 \pm 0.38$ ) respectively. Among the fungal strains, Aspergillus flavus had maximum zone of inhibition (6.1 \pm 0.62 ). Moreover, least zone of inhibition was found for Penicillium pinophilium $(3.1 \pm 0.17)$. Bacterial strains had similar results

Table 3. Antibacterial activity of essential oils using Agar diffusion method

\begin{tabular}{|c|c|c|c|}
\hline \multirow[t]{2}{*}{ Microorganisms } & \multicolumn{3}{|c|}{ Zone of Inhibition in diameter $(\mathrm{mm})$} \\
\hline & GEO & FEO & $\begin{array}{c}\text { Tetracycline } \\
(50 \mu \mathrm{g} / \mathrm{ml})\end{array}$ \\
\hline Rhodococus equi & $13.2 \pm 0.18$ & $3.0 \pm 0.41$ & $22.3 \pm 0.31$ \\
\hline Bacillus cereus & $18.1 \pm 0.31$ & $6.8 \pm 0.26$ & $31.1 \pm 0.38$ \\
\hline Enteococcus faecalis & $9.7 \pm 0.53$ & $5.2 \pm 0.13$ & $24.7 \pm 0.27$ \\
\hline Staphylococcus aureus & $15.4 \pm 0.19$ & $4.2 \pm 0.08$ & $27.1 \pm 0.32$ \\
\hline Listeria monocytogenes & $5.2 \pm 0.21$ & $1.5 \pm 0.06$ & $19.8 \pm 0.22$ \\
\hline Escherichia coli & $18.5 \pm 0.28$ & $5.1 \pm 0.24$ & $21.6 \pm 0.39$ \\
\hline Enterobacter aerogenes & $17.3 \pm 0.41$ & $4.0 \pm 0.08$ & $25.2 \pm 0.41$ \\
\hline Cronobacter sakazakii & $10.3 \pm 0.61$ & $3.6 \pm 0.23$ & $22.6 \pm 0.37$ \\
\hline Klebsiella pneumonia & $8.7 \pm 0.46$ & $3.7 \pm 0.0$ & $18.8 \pm 0.26$ \\
\hline Pseudomonas aeruginosa & $13.5 \pm 0.39$ & $3.7 \pm 0.14$ & $19.4 \pm 0.32$ \\
\hline Citrobacter freundii & $11.7 \pm 0.32$ & $4.0 \pm 0.00$ & $23.4 \pm 0.41$ \\
\hline Clostridium perfringens & $4.5 \pm 0.35$ & $4.0 \pm 0.45$ & $20.7 \pm 0.26$ \\
\hline Micrococcus luteus & $20.8 \pm 0.28$ & $5.0 \pm 0.37$ & $29.5 \pm 0.53$ \\
\hline Salmonella typhi & $14.6 \pm 0.29$ & $3.5 \pm 0.36$ & $18.3 \pm 0.28$ \\
\hline Vibrio parahaemolyticus & $5.1 \pm 0.25$ & $3.9 \pm 0.09$ & NT \\
\hline Vibrio cholerae & $5.7 \pm 0.24$ & $6.1 \pm 0.34$ & NT \\
\hline Salmonella enterica & $12.7 \pm 0.23$ & $2.5 \pm 0.08$ & $18.2 \pm 0.31$ \\
\hline Shigella & $10.6 \pm 0.67$ & $2.0 \pm 0.00$ & $9.6 \pm 0.48$ \\
\hline Enteococcus hirae & $18.5 \pm 0.41$ & $4.3 \pm 0.19$ & $19.8 \pm 0.36$ \\
\hline Listeria ivanovii & $5.6 \pm 0.35$ & $1.6 \pm 0.29$ & NT \\
\hline Listeria innocua & $6.3 \pm 0.24$ & $1.8 \pm 0.08$ & NT \\
\hline
\end{tabular}

Values are expressed as Mean \pm SEM (Standard Error of Means), NT; Not Tested 
varying from $(1.5 \pm 0.06-6.8 \pm 0.26)$. The antimicrobial activity of GEO and FEO could be due to the collective effect of tannins, phenolic compounds, flavonoids, alkaloids, and terpenoids present in oil29.

\section{CONCLUSIONS}

The antimicrobial activity against the broad range of tested microorganism indicates the presence of wide spectrum of antimicrobial compounds in Garlic and Fenugreek essential oils. Additionally, antimicrobial components showed by GC-MS/MS analysis could be a good source of food preservation rendering the growth of microbes. In conclusion, it is suggested that these plant-derived products could be valuable to find out natural bioactive compounds. More importantly, these can be incorporated in the list of food preservation system due to their antimicrobial activity and lesser side effects. Hence, essential oils and their chemical components can be recommended for food preservation.

\section{ACKNOWLEDGEMENTS}

We are grateful to the Department of Clinical Nutrition, College of Applied Medical Sciences, Hail University and Department of Food technology, Hamdard University, New Delhi, and for encouragement and providing facilities to carrying out the present study.

\section{CONFLICTS OF INTEREST}

The authors declare that there is no conflict of interest.

\section{FUNDING}

None.

\section{AUTHORS' CONTRIBUTION}

All authors listed have made a substantial, direct and intellectual contribution to the work, and approved it for publication.

\section{DATA AVAILABILITY}

All datasets generated or analyzed during this study are included in the manuscript and/or the Supplementary Files.

\section{ETHICS STATEMENT}

This article does not contain any studies with human participants or animals performed by any of the authors.

\section{REFERENCES}

1. Hyldgaard M, Mygind T, Meyer RL. Essential oils in food preservation: mode of action, synergies, and interactions with food matrix components. Front. Microbiol., 2012; 25(3): 1-24. https://doi.org/10.3389/ fmicb.2012.00012

2. Djenane D, Yanguela J, Roncales P, Aider M. Use of essential oils as natural food Preservatives: Effect on the growth of Salmonella Enteritidis in liquid whole eggs stored under abuse refrigerated conditions. J. Food. Res., 2013; 2(3): 65-78. https://doi.org/10.5539/ jfr.v2n3p65

3. Zhao CX, Liang YZ, Fang HZ, Li XN. Temperatureprogrammed retention indices for gas chromatographymass spectroscopy analysis of plant essential oils. J. Chromatogr. A., 2005; 25; 1096(1-2): 76-85. https:// doi.org/10.1016/j.chroma.2005.09.067

4. Ebrahimi M, Khosravi-Darani K. Essential oils as natural food preservatives: Antimicrobial and antioxidant applications.7 Antimicrobials from Nature: Effective Control Agents for Drug Resistant Pathogens, Edition: first, Chapter: 1. Publisher: Transworld Research Network, Editors: James Hamuel Doughari, 2013; p.15-37.

5. Ashraf SA, Al-Shammari E, Hussain T, Tajuddin S, Panda BP. In-vitro antimicrobial activity and identification of bioactive components using GC-MS of commercially available essential oils in Saudi Arabia. J. Food Sci. Technol., 2017, 54: 3948-3958.

6. Dash BK, Sultana S, Sultana N. Antibacterial activities of methanol and acetone extracts of Fenugreek (Trigonella foenum) and Coriander (Coriandrum sativum). Life Sciences and Medicine Research, 2011; 27: 1-8.

7. Wallock-Richards D, Doherty CJ, Doherty L, Clarke DJ, Place M. Garlic Revisited: Antimicrobial Activity of Allicin-Containing Garlic Extracts against Burkholderia cepacia Complex. PLoS ONE, 2014; 9(12): e112726. https://doi.org/10.1371/journal.pone.0112726

8. Anees AM, Ravi S, Ghogare P. Studies on antimicrobial activity of spices and effect of temperature and $\mathrm{pH}$ on its antimicrobial properties. IOSR Journal of Pharmacy and Biological Sciences, 2015; 10(1): 99-102.

9. Iwalokun BA, Ogunledun A, Ogbolu DO, Bamiro SB, Jimi-Omojola J. In-vitro antimicrobial properties of aqueous garlic extracts against multidrug-resistant bacteria and candida Species from Nigeria. J. Med. Food., 2004; 7(3): 327-333. https://doi. org/10.1089/1096620041938669

10. El-Nour MEM, Ali MAA, Saeed BEAE. Antimicrobial activities and phytochemical screening of callus and seeds extracts of Fenugreek (Trigonella foenumgraecum). Int. J. Curr. Microbiol. App. Sci., 2015; 4(2): 147-157. 
11. Ramya P, Sudisha J, Devi NL, Aradhya SM, Antibacterial and anti-oxidant activities of fenugreek (Trigonella foenum graceum L.) leaves. Res. J. Med. Plant., 2011; 5(6): 695-705. https://doi.org/10.3923/ rjmp.2011.695.705

12. Balouiri M Sadiki M, Ibnsouda SK. Methods for in vitro evaluating antimicrobial activity: A review. J. Pharm. Anal., 2016; 6: 71-79. https://doi.org/10.1016/j. jpha.2015.11.005

13. Burt S. Essential oils: their antibacterial properties and potential applications in foods -a review. Int. J. Food Microbiol., 2004; 1; 94(3): 223-253. https://doi. org/10.1016/j.ijfoodmicro.2004.03.022

14. Reeves DS. Antibiotic assays. Hawkey PM, Lewis DA(Eds.) Medical bacteriology, A Practical approach. IRL Press, Oxford. 1989; 195-221.

15. Raid AA, Yazeed AS, Ayesha M, Rabbani SK, Janardhan C, Gupta VC. Evaluation of antibacterial activity of crude protein extracts from seeds of six different medical plants against standard bacterial strains. Saudi. J. Biol. Sci., 2014; 21(2): 147-151. https://doi. org/10.1016/j.sjbs.2013.09.003

16. Kim JW, Huh JE, Kyung KH. Antimicrobial activity of alk(en)yl sulfides found in essential oils of garlic and onion. Food Sci. Biotechnol., 2004; 13(2): 235-239.

17. Banerjee S, Mukherjee K, Maulik S. Garlic as an antioxidant: The good, the bad and the ugly. Phytother. Res., 2003; 17(2): 97-106. https://doi.org/10.1002/ ptr.1281

18. Satyal P, Craft JD, Dosoky NS, Setzer WN. The chemical compositions of the volatile oils of Garlic (Allium sativum) and Wild Garlic (Allium vineale). Foods, 2017; 6(63). https://doi.org/10.3390/foods6080063

19. Gupta R, Sharma A, Maina P, Shukla RN. Study of chemical composition of garlic oil and comparative analysis of co-trimazole in response to in-vitro antibacterial activity. Int. Res. J. Pharm. 2014; 5(2): 97-101. https://doi.org/10.7897/2230-8407.050220

20. Bano DH, Tabassum A, Ahmad A, Mabood, Ahamd IZ. The medicinal significance of the bioactive compounds of trigonella foenum-graceum: A review. Int. J. Res. Ayurvadic Pharm., 2016; 7(4): 84-91. https://doi.

\section{org/10.7897/2277-4343.074139}

21. Sohrevardi N, Sohrevardi F. Essential oil composition and antioxidant activity of Trigonella foenum graecum L. plant. Int. J. Agri. Crop Sci., 2012; 4(12): 793-797.

22. Babu JA, Sundari AR, Indumathi J, Srujan RVN, Sravanthi M. Study on the antimicrobial activity and minimum inhibitory concentration of essential oils of spices. Vet. World., 2011; 4(7): 311-316. https://doi.org/10.5455/ vetworld.4.311

23. Leontiev R, Hohaus, N, Jacob C, Martin CH, Gruhlke, Alan J, Slusarenko. A comparison of the antibacterial and antifungal activities of thiosulfnate analogues of allicin. Sci. Rep., 2018; 8: 6763. https://doi. org/10.1038/s41598-018-25154-9

24. Kyung $\mathrm{KH}$. Antimicrobial properties of allium species. Curr. Opin. Biotechnol., 2012; 23(2): 142-147. https://doi.org/10.1016/j.copbio.2011.08.004

25. Chekki RZ, Ahmad S, Imen H, Nabiha B. Chemical composition, antibacterial and antioxidant activities of Tunisian garlic (Allium sativum) essential oil and ethanol extract. Mediterr. J. Chem., 2014; 3(4): 947956. https://doi.org/10.13171/mjc.3.4.2014.09.07.11

26. Mousumi B, Sarkar PK. Inhibitory effect of garlic on bacterial pathogens from spices. World J. Microbiol. Biotechnol., 2003; 19(6): 565-569. https://doi. org/10.1023/A:1025108116389

27. Al-Waili NS, Saloom KY, Akmal M, Al-waili TN, Al-Waili AN, Al-Waili H, Ali A, A-Sahlani K. Effects of heating, storage and ultraviolet exposure on antimicrobial activity of garlic juice. J. Medicinal Food, 2007; 10(1): 208-212. https://doi.org/10.1089/jmf.2005.067

28. Alluri N, Majumdar M. Phytochemical analysis and in vitro antimicrobial activity of Calotropis gigantea, Lawsonia inermis and Trigonella foecum-graecum. Int. J. Pharm. Pharm. Sci., 2014. 6(4): 524-527.

29. Moniruzzaman, Shahinuzzaman, Haque A, Khatun R, Yaakob Z. Gas chromatography- mass spectrometry analysis and in vitro antibacterial activity of essential oil from Trigonella foenum-graecum. Asian Pac. J. Trop. Biomed., 2015; 5(12): 1033-1036. https://doi. org/10.1016/j.apjtb.2015.09.010 